\title{
KAMU HUKUKU
}

\section{CEZALANDIRILABILME OBJEKTIF ŞARTI (SARTLI SUÇLAR)}

Yazan : Prof. Dr. Faruk EREM

Kanunumuz bu kavramdan müstakil bir hükümde, açıkca söz etmiş değildir. Fakat bu kavramın bazı suçlara ilişkin hükümler. de uygulandı̆̆ı görüilmektedir.

«Suçu cezalandırabilme objektif şartı» deyimi yerine «fiili (hareketi) cezalandırabilme objektif şartı» demek daha doğrudur. Bununla beraber, esasında cezalandırılması gereken «suç» un cezalandırılmasının, açı bir kanun hükmü ile, «talikî șart» a bağlanması yolundaki anlayış benimsenirse «suç» tan bahsetmekte çelişme kalmaz'.

«Objektif şart» deyimi, suçta bir de «sübjektif cezalandırabilme şart» 1 bulunduğu zannını uyandırabilir. Nitekim «isnadiyet» 1 sübjektif şart sayanlar vardır². Fakat isnadiyette şart niteliği yoktur.

Yeni Italyan Ceza Kanumunda (m. 44) ve genel hükümlerde kurala rastlanmaktadır: "Bir suçun cezalandırılabilmesini, kanun bir şartın tahakkukuna bağlamış' ise, şart sayılan istenmemiş olsa dahi fail suçtan sorumludurs ${ }^{3}$. Bu suretle İtalyan Kanunu cezalandr-

\footnotetext{
I Sabatini (G.), Istituzioni di diritto penale (Catania, 1946) I, n. 190

2 bk. Battaglini (G.), Il diritto di querela (Bologna, 1939), s. 47

3 Italyan Kanununun bu hükmü şöylece yerilmektedir : Bütün unsurları ile tamamlandığı halde, sart tahakkuk etmediğinden bir suçun cezasız kalabileceği zannı uyanmaktadır. But itibarla deyim isabetli değildir. Cezalandirılmayana suç denemez. (bk. Battaglini (G.), Diritto penale (Bologna, 1940), s. 210). bk. Bettiol (1955), s. 170
} 
rilabilmeleri, bir olayın vukuuna bağlı suçlar ( $=$ şartlı suçlar) da, istenmemiş bir olayın vukuu halinde, iradeye dayanan bir sistem. de failin cezalandırılıp cezalandırılmayacağı hususundaki tereddüdü gidermiștir. Fakat konu, «kusursuz ceza olmaz» kuralı önünde pek önem kazanir4.

1. Şartl suçların yaptst : Şartlı suçların teknik yapısı üzerinde de durmak lâzımdır. Bu suçlar şartın tahakkukundan evvel de mevcut mudurlar? Şart ancak cezalandırmak için mi aranır? Eğer suç şrttan evvel de meydana gelmiş sayılırsa, bundan, cezalandırma dışında kalan konularda farklı çözümlere varmak gerekecektir.

Cezalandırabilme objektif şartı, "suçun unsurları" ndan ve "suç durumlarn» ndan ayrıdır".

Bir anlayışa göre kanun koyucu "ceza politikası» uyarınca, belli bir sonuç meydana getirmemiş ise bir hareketi cezalandırmak istememiştir. Bu gibi hallerde «suçsuz ceza olmaz" kuralı, "suçsuz ve şartsız ceza olmaz» șeklinde değiştirilmiştir ${ }^{6}$. Suç, soyut olarak cezayı gerektirmektedir. Fakat somut olarak cezalandırılması için belli bir șart aranır?.

Aynı etkiyi ceza hukukunda, ters yönden sağlayan başka sebspler yok değildir. «Yalan şahadetten dönme» de (TCK. 289)', «suç ortaklarını ihbar» da (TCK. 404/3) cezayı kaldıran haller, suçun bütün unsurları tamamlandıktan sonra meydana gelirler.

Şart kavramının ceza hukukunda lüzumsuzluğuna inananlar da vardır. Eğer bir fiil cezalandırılamıyorsa suç değildir, o halde cezalandırılabilme şartı, suç olmanın şartı demektir'. Buna mukabil genellikle cezalandırabilme objektif şartı kavramını faydalı, kanun koyucunun suçun objektif bütününden bir parçayı ayırarak onu suçun dışında ayrı bir dïzene bağlamasının isabetli ve yasama işlemlerinde meşru olduğuna inanmaktadırlar ${ }^{10}$. Meselâ kanun,

4 «Dâva şartları" ayn bir konudur. Usul hukukuna girer; bk. Erem (Usul),

2. Bası, s. 177; Manzini, I, n. 215 , s. 429 , nt. 1

5 Sabatini (G.), Istituzioni di diritto penale (Catania, 1946), I, n. 182

- Curatola (P.), Condizioni obiettive di punibilità (Enciclopedia del diritto,

VIII), s. 807

7 bk. Battaglini, s. 211

8 Sabatini, I, n. 183

9 bk. Bettiol (1955), s. 170

${ }^{10}$ Battaglini, s. 213 
rezalet çıkarmazsa sarhoşu cezalandırmamakta, Türkiye'de değil ise suçluyu giyapta cezalandırmamakta fayda görebilir.

Diğer bir anlayıs «unsur» ile "şart» arasındaki farka dayanır: Bu çeşit suçlarda şart, kronolojik bir farkla unsurdan ayrilmıştır. Şart, unsur değildir, fakat suçun organizması dışında da değildir."

Unsur-şart farkını kaldırmağa yönelmiş anlayışlar da vardır: Belli organlarla doğan kişi insandır. Fakat yaşaması için oksijen şarttrr. İște bu benzetmede olduğu gibi suç bütün özellikleri ile vücut bulmuş, fakat henüz yaşamağa başlamamıştr1r' ${ }^{12}$.

Cezalandırabilme objektif şartında «esasa ilișkin olmayan objektif bir unsur", "tipik hareketten ayrı olarak nazara alınmış unsur», "suçun maddî olarak mevcut sayılabilmesi için aranan», "kusurluluk ile alâkası olmayan unsur» niteliği görenler vardır ${ }^{13}$.

Suç teorisi içinde ele alınan «netice» ile "şart» kavramın ayırt etmek kolay değildir. Neticenin şart olamıacağını kesinlikle iddia edenler vardır'14. Fakat aynı konunun hukukta başka başka yönlerden izahına örnekler bulunabilir. Bazan netice șart olarak kanunda gösterilmiştir, gebe sanılan kadının ölümü veya zarar görmesinin cezalandurabilme şartı sayılması gibi. Bazan şart sayılan halin, hareketin neticesi ile hiç bir ilgisi yoktur, yabancı ülkede ișlenen suçlardan cezalandırabilme için failin Türkiye'de bulunması şartı gibi.

Özel hukukta şart kişi iradesine dayanır. Şartlı suçlardaki şart ise daima kanun kuralindan gelir.

2. Kronolojik açıdan şart : \$artın gelecek bir olaya ilişkin ol. ması gerektiği kabul edilmekle beraber, fiil ile aynı zamanda vukua gelen veya fiilden evvel mevcut bulunan bir olaya ilişkin bulunabileceğini ileri sürenler de vardır. Bir kimsenin kendisine gönderilen mektubu gönderenin rzzası hilâfına yayınlamasının cezalandırnlabilmesi için bu yüzden bir zararın vukuu şartı (TCK. 197), bazı sahtelik suçlarında zararn husulü şartı (TCK. 343, 348), hattâ zarar ihtimali şartı (TCK. 339), intihara azmettirme suçunda ölümün meydana gelmesi șartı (TCK. 454), gebe sanılan kadın uizerindeki

\footnotetext{
"Battaglini, s. 211

12 bk. Curatola, s. 810; kşz. Carnelutti (F.), Teoria generale del reato (1933),

s. 51; k\$s. Battaglini, s, 211

13 Battaglini, s. 211

14 Sabatini, I, n. 183, 184
} 
ameliyeler sonunda kadının ölümü veya bedenî zarara ưğraması şartı (TCK. 470) konusu sonradan vukua gelen şarta örnek gösterilebilir. Belli bir şekilde sarhoş olarak yakalanmak suçunda böyle bir halin vukuu șartı (TCK. 571), üzerinde maymuncuk ve emsali aletlerle yakalanıp bunları o anda meşru surette nerede kullanacağın isbat edememek şartı (TCK. 578/2) fiil ile aynı zamanda mey. dana gelen olay konulu şarta, bazı hileli iflâs suçları, bazı suçların takibi için Türkiye'de bulunmak (TCK. 5, 6) ise evvelden mevcut şarta örnek gösterilmektedir ${ }^{15}$.

Başka bir anlayıs gelecekteki bir olay veya fiil ile aynı zamanda vukua gelen olay konulu şartı mümkün görmekte, evvelden mevcut bir halin şart sayılmasını red etmektedir. Bu düşünceye, kanunlarında şartlı suçlarda zamanaşımının ne zaman başlayacağı hakkında hüküm bulunan sistemlerde rastlanır. Örneğin Italyan Ceza Kanununda şöyle bir hüküm vardır: "Cezalandırılmasını kanunun bir şartın tahakkukuna bağladığı suçlarda zamanaşımı süresi şartın tahakkuk ettiği günden islemeğe başlar» ${ }^{16}$. O halde bu hükme göre ancak fiil ile aynı zamanda veya gelecekte bir olaya davanan şartı kanun kabul etmiştir. Bu sonucun böyle bir hüküm bulunmamasına rağmen kanunumuz için de doğru olduğunu sanıyoruz. Zira genel hukuk teorisinde sart kavramı, tahakkuk edip etmeyeceği bilinmeyen bir olay da düşünülebilir. Evvelden mevcut olana şart denemez.

3. Sart ve önsart ayrtmt : "Cezalandurabilmenin objektif sart1" ile "suçun önşartı" kavramları birbirlerinden farklıdır.

Suçun önsartı kavramında, "hareket» in evvelinde yer alan ve varlk veya yoklukları suçun yokluğuna veya - diğer unsurlar mevcut ise- varlığına etkili olmaklık yer alır. Ancak belli sıfatlı kişilerin (örneğin memurların) ișleyebilecekleri suçlarda «memurluk sıfatı" önsarttır. Eğer bu önșart bulunmuyorsa "suc vasfı" değisir, örneğin «zimmet" suçu "emniyeti suiistimal» e döner veya önsartın olmaması fiili suç olmaktan çıarır ${ }^{17}$. Buna mukabil \$artlı sıclarda, hareket ya suçtur veya dę̧ildir, bașka vasfa dönmez. Önsartta hareketten evvel olmak tabîidir. \$̧art, hareketle aynı zamanda veya ondan sonra vukua gelecek bir olayı konu tutabilir. Hareketten evvel mevcut olanı konu sayan şartın mevcut olup olama-

15 bk. Curatola, s. 811; Battaglini, s. 177, 211; Manzini, I, n. 216; Sabatini, I, n. 183; Bettiol (1955), s. 170

16 Italyan CK. 44, 158; bk. Curatola, s. 811; Manzini, I, n. 216

${ }^{17}$ Manzini (V.), Trattato di diritto penale italiano (Torino, 1926), I, n. 216 
yacağı tartışmahdır. Bizce olamaz. "İcabî veya selbî fiilin dışında, hareketle ayn zamanda veya ona muahhar ve mevcut olmazlarsa fiilin cezalandırılması imkânsız unsurlara cezalandırabilme șartı denir" yolunda tanım da ${ }^{\text {is }}$ - genellikle- isabet vardır.

Bir anlayıșa göre önșartın kanunî veya fiilî olarak ikiye ayrnlması mümkündür. "Zimmet» suçunda "memurluk» önșartı kanunî, çocuk düş̧ürmede gebelik fiilî anlamda önşarttır. Fakat bu ayırımın «cezalandırabilme objektif şartı» kavramı açısından bir etkisi yoktur ${ }^{19}$.

4. Taksirli suçlar: Bu çeşit suçlarda "netice» vukua gelmezse faile ceza verilmediğine göre neticenin "cezalandırabilme objektif şartı" sayılıp sayılamayacağında tereddüt edilebilir. Zannımızca taksirli suçlarda netice, şart olarak da kabul edilebilir. Fakat kasıtlı suçlardaki şart ile taksirli suçlardaki şart arasında bazı farkların bulunacağı da sezilmektedir ${ }^{20}$.

5. Suç duruları: Şart ile "suç duruları" (= cezayı arttıran, indiren sebepler) kavramlarını karıștırmamak lâzımdır. Șart, cezalandırmada objektif bir vakıa olarak müdahale eder, görevi cezalandırmayı sağlamaktır. Suç duruları, suçun maddî bünyesi içindedir, şartta dışardan gelen bir nitelik vardır.

Bununla beraber «șart niteliğinde suç duruları diğer durulardan tecrit edilebilirir". Bunlarda suçun maddî bünyesi dıșından gelen bir özellik vardır: Bazı bilgilerin açıklanması suçtur (TCK. 137), bunların harp zamanında açılanmıs olması ise şiddet sebebidir (TCK. 137/2). Harp zamanına «eğer harp vukua gelmiş ise seferberlik zamanı da dahildir" (TCK. 173/2). Göruiliuyor ki burada sonradan meydana gelen, şarta çok yaklașan bir şiddet sebebi bahis konusudur.

6. Umanist doktrin açıstndan şartl suçlar: Umanist doktrin açısından "şartlı suç» konusu "nedensellik» kavramı içinde incelenmelidir. Zira önemli olan «șart» değil, şarta bağlı sorumluluk ve cezalandırmadır.

Bir anlayışa göre failin yaptığı «hareket», şartın maddî sebebidir. Bu itibarladır ki failin isteği nazara alınmaz. Diğer bir anlayı-

18 Manzini, I, n. 216

19 Bettiol (G.), Il diritto penale (Palermo, 1955), ss. 165

${ }^{20} \mathrm{kşz.}$ Curatola, s. 813; Battaglini, s. 211; bk. Manzini, I, n. 216

21 bk. Battaglini, s. 213; bu konu daha fazla Alman doktrininde geliştirilıı ıs miştir; bk. Alman (1870) CK. $\$ 59$; 
şa göre șart ile hareket arasında maddî sebebiyet alâkası bulưnabilir, fakat zaruñ değildir. Bir başka anlayıșta olanlara göre de hareket ile şart arasinda ne «kusurluluk» ve ne de «nedensellik» aranmalidir.

Bütün bu açıklamalarda konuyu izah sıkıntısı sezilir ${ }^{2}$. Irade ve şuura dayanan bir ceza hukukunda nedensellik dışı sorum, sistemin düzenini bozar. Bu sebeple şartlı suç konusunun izahı "tabiatcı nedensellik» ile mümkün değildir. «Ümanist nedenseliik» anlayıșı ve «insanın hükmedebilecȩ̌i alan» ölçüsü hem şartlı suçları izah eder, hem de uygulamada aşırılıkları önler ${ }^{23}$. Bir fiili şartsız cezalandırmakla şartlı cezalandırmak arasında ümanist takdire giren bir nitelik vardır. Konuyu «hukuka aykırılık» açısından incelemek teklifinde ${ }^{24}$ aynı yapıcılığı görmekteyiz.

$z$ bk. Battaglini, s. 211

${ }^{23} \mathrm{kşzz.} \mathrm{Curatola,} \mathrm{s.} 811$

${ }^{24}$ bk. Petrocelli, Principi di diritto penale (Napoli, 1955), I, n. 96 